\title{
O LEKSYCE NACECHOWANEJ STYLISTYCZNIE W NAUCZANIU BIAŁORUSINÓW JĘZYKA POLSKIEGO
}

\begin{abstract}
Słowa kluczowe: leksyka nacechowana stylistycznie, błąd glottodydaktyczny, glottodydaktyka porównawcza, język polski, język białoruski

Streszczenie. Artykuł dotyczy leksyki nacechowanej stylistycznie w nauczaniu języka polskiego Białorusinów. Szczególna uwaga zwracana jest na niuanse stylistyczne różniące leksemy polskie i białoruskie, które z pozoru wydają się bardzo do siebie podobne. Zebrany materiał może pomóc lektorom pracującym z Białorusinami w akcentowaniu poszczególnych kwestii stylistycznych w nauczaniu JPJO, a Białorusinom uczącym się języka polskiego - w unikaniu błędów stylistycznych.
\end{abstract}

Rozmaite kwestie (glotto)dydaktyczne (ale też socjolingwistyczne czy historyczne) w parze językowej polsko-białoruskiej były poruszane przez różnych badaczy polskich i białoruskich (np.: Cukrowska 1978; Kuźmiuk 1982; Šuba 1993; Biełocka 1997; Šakun 1999; Smułkowa 2001, 2002, 2007; Guszczewa 2006; Kaleta 2010, 2014, 2015). Przedmiotem badań był głównie transfer negatywny i jego rozmaite konsekwencje w glottodydaktyce. Niniejszy artykuł ma za zadanie zwrócenie uwagi na polską leksykę nacechowaną stylistycznie ${ }^{1}$, która ma w języku białoruskim swoje odpowiedniki neutralne stylistycznie. Konsekwencją tego może być posługiwanie się przez Białorusinów² uczących się języka polskiego w ich mniemaniu neutralnymi polskimi leksemami, które jednak dla rodzimego użytkownika języka takie nie są. Temat był już sygnalizowany w innych pracach

*rkaleta@uw.edu.pl; Pracownia Glottodydaktyki Białorutenistycznej, Katedra Białorutenistyki, Wydział Lingwistyki Stosowanej, Uniwersytet Warszawski, 02-678 Warszawa, ul. Szturmowa 4.

${ }^{1}$ Leksemy nacechowane stylistycznie rozumiemy jako te, które w słownikach opatrzone są kwalifikatorem stylistycznym, np. potocyzmy, lub kwalifikatorem chronologicznym, np. archaizmy, w odróżnieniu od leksemów neutralnych, czyli tych, które nie są opatrzone w słownikach żadnym kwalifikatorem i często należą do leksyki podstawowej, np. dom.

${ }^{2}$ Zarówno białoruskojęzycznych, jak i rosyjskojęzycznych, gdyż nawet rosyjskojęzyczni Białorusini przy nauce języka polskiego często odwołują się do języka białoruskiego, który w ich mniemaniu jest bliższy polskiemu niż rosyjski (zob. Guszczewa 2006). 
np. (Kaleta 2013, 136-137; 2015a i 2015b). Podobne zagadnienia (choć różnie nazywane, por. Kaleta 2015b) były opisywane na przykładzie innych par języków, np. w parze polsko-rosyjskiej (np. Grosbart 1984, s. 119; Stasin'ska 1990, s. 34-42; Gasek 2012, s. 73-76), w parze polsko-słowackiej (Pančíková 2004, s. 283, 285; Pančíková 2005), w parze polsko-czeskiej (Lotko 1992) czy w relacji polsko-ukraińskiej (Bednaž 2002). Różnice w rejestrach stylistycznych mogą być przyczyną błędów przekładowych czy glottodydaktycznych, na co zwracano uwagę także w poradniku dla nauczycieli języka polskiego pracujących na Wschodzie, np. *Jeszcze będac uczennica, uczestniczyłam $w$ wycieczkach archeologicznych, lubiłam ekskursje do różnych historycznych miejsc (Dąbrowska, Dobesz, Pasieka 2010, s. 61; por. Foland-Kugler 1998).

W niniejszym artykule zostaną zaprezentowane nacechowane stylistycznie polskie leksemy, które mogą być odbierane przez Białorusinów uczących się języka polskiego jako neutralne ze względu na fakt, że ich białoruskie odpowiedniki nie są nacechowane stylistycznie (por. Kaleta 2011; 2014, s. 53-54, 68, 89-98). To właśnie może stanowić przyczynę błędu stylistycznego (por. Kaleta 2013), np. zamiast powiedzieć/napisać Gratuluję! Białorusini często mówią/piszą Winszuję, a jeszcze częściej z błędną końcówką przeniesioną z języka ojczystego - *Winszuju. Należy zatem uświadomić zwłaszcza początkującym uczącym się z Białorusi, że do polskiego języka mówionego (czy do wypowiedzi pisemnej, którą konstruują w ramach ćwiczeń) nie pasuje książkowy leksem winszować, chociaż jego użycie nie zakłóca komunikacji. Na potrzeby niniejszego artykułu wybrano tylko takie nacechowane stylistycznie leksemy polskie, które w języku białoruskim mają odpowiedniki neutralne stylistycznie bardzo podobne do polskich leksemów, stanowiące z nimi w jakimś zakresie paronimy lub homonimy międzyjęzykowe. Polskie przykłady zaczerpnięto ze Słownika języka polskiego PWN (online) i Stownika SJP.PL (online), białoruskie zaś ze Stownika białorusko-polskiego (Chylak-Schroeder, Głuszkowska-Babicka, Jasińska-Socha 2012), ale na potrzeby artykułu będą zapisywane w transliteracji. Wybrane polskie leksemy są w słownikach języka polskiego oznaczane zwykle różnymi kwalifikatorami stylistycznymi, np.: książ. (książkowy), poet. (poetycki), pot. (potoczny), reg. (regionalny), choć często słowniki w różnych sposób klasyfikują ten sam leksem.

W nauczaniu Białorusinów języka polskiego jako obcego warto zwrócić uwagę na poniższe leksemy i omówić ich rejestr stylistyczny:

pol. cyrkulować ksiażk. 1. «być w obiegu; krążyć, obiegać, płynąć»; 2. pot. «poruszać się po określonym obszarze» - białoruski odpowiednik neutralny cyrkulâvac' 'krążyć, obiegać'.

pol. podzięka podn. «podziękowanie» - białoruski odpowiednik neutralny padzâka 'podziękowanie, wdzięczność, podzięka';

pol. publika pot. «widzowie jakiegoś zdarzenia lub publiczność» - białoruski odpowiednik neutralny publika 'publiczność'; 
pol. ruczaj poet. «potok, strumień» - białoruski odpowiednik neutralny ručaj 'strumień, potok';

pol. sobaka 1. pot. «pies» 2. pot. «rodzaj wyzwiska»-białoruski odpowiednik neutralny sabaka 'pies';

pol. winszować książk.1. składać komuś życzenia; życzyć; 2. składać komuś gratulacje; gratulować - białoruski odpowiednik neutralny vinšavac' 'gratulować';

W tym ostatnim przypadku, by zapobieć innym błędom językowym, należy także zwrócić uwagę na rekcję; w polszczyźnie czasownik winszować wymaga celownika i dopełniacza, np. Winszuję panu awansu, a w języku białoruskim - biernika i narzędnika, np. Vinšuû vas z avansam, gratuluję panu / pani awansu', a dosłownie * gratuluje pana/pania z awansem).

W słownikach nie zawsze wszystkie znaczenia polskiego leksemu są opatrzone kwalifikatorem stylistycznym, co nie ułatwia obcokrajowcom nauki, np.:

pol. dola 1. «los przypadający komuś w udziale» 2. pot. «część przypadająca na kogoś z podziału zdobyczy, zarobionych wspólnie pieniędzy m.in.» - białoruski neutralny odpowiednik dolâ 1. 'część', 2. 'udział', 3. 'dola, los';

pol. dziad 1.podn. «ojciec ojca lub matki» 2. «przodek» 3.pot. «biedak lub żebrak» 4. pogard. «starzec» 5.pot. «z niechęcią lub obraźliwie o mężczyźnie» 6. reg. «rzep» - białoruski neutralny odpowiednik dzed 'dziadek, dziad' . pol. wodzić 1. książk. a). 'idąc, prowadzić kogoś w różne miejsca, być czyimś przewodnikiem', b) 'przesuwać coś po czymś'), 2. zool., zootechn. 'o samicach ptaków, opiekować się wyklutymi pisklętami do osiągnięcia przez nie dojrzałości, samodzielności' (Dubisz 2003, s. 159-160) - białoruski neutralny odpowiednik vadzic' 1. 'prowadzić', 2. 'wodzić' (ołówkiem po mapie);

Oprócz leksemów, które w słownikach mogą być opatrzone kwalifikatorami stylistycznymi, w polszczyźnie występują także leksemy, które w słownikach mogą być opatrzone kwalifikatorami chronologicznymi, takim jak: arch. (archaiczny), daw. (dawny), przestarz. (przestarzaty) (więcej o archaizmach zob. Dubisz 1991; Zdunkiewicz-Jedynak 2006). Niektóre leksemy są oznaczone dodatkowymi kwalifikatorami (np. chronologicznym, stylistycznym), np.: pol. śniadać prze-

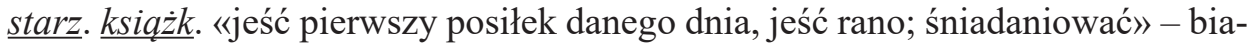
łoruski neutralny odpowiednik snedac' 'jeść śniadanie'. Jedno ze znaczeń może być opatrzone kwalifikatorem chronologicznym, a drugie stylistycznym, np. pol. krynica 1. daw. «źródło» 2. poet. «miejsce pochodzenia czegoś»-białoruski neutralny odpowiednik krynica 'źródło'.

Poniżej kolejne przykłady nacechowanych stylistycznie polskich leksemów i ich białoruskich neutralnych odpowiedników:

pol. aerodrom daw. «lotnisko» - białoruski neutralny odpowiednik aèradrom 'lotnisko';

pol. arenda 1. daw. «dzierżawa» 2. daw. «opłata za dzierżawę» - białoruski neutralny odpowiednik arènda 1. 'dzierżawa', 2. 'czynsz dzierżawny'; 
pol. automobil daw. «samochód (dziś używane w odniesieniu do zabytkowych samochodów)» (por. Kaleta 2013, s. 137) - białoruski neutralny odpowiednik aŭtamabil' 'samochód';

pol. awiacja daw. «lotnictwo» - białoruski neutralny odpowiednik aviâcyâ 'lotnictwo';

pol. awiator daw. «lotnik» - białoruski neutralny odpowiednik aviâtar 'lotnik';

pol. cyrulik daw. «fryzjer wykonujący również zabiegi felczerskie» - białoruski neutralny odpowiednik cyrul'nik 'fryzjer';

pol. cytatata daw. «słowa przytoczone dosłownie z jakiegoś tekstu pisanego lub z czyjejś wypowiedzi ustnej (cytat)»- białoruski neutralny odpowiednik cytata 'cytat';

pol. dobrodziej daw. «dobroczyńca» - białoruski neutralny odpowiednik dabradzej 'dobroczyńca';

pol. dychać daw. «oddychać, zwłaszcza głośno, z trudem» (por. Kaleta 2013, s. 136) - białoruski neutralny odpowiednik dyhac' 'oddychać';

pol. ekskursja daw. «wycieczka, wyprawa» (por. Kaleta 2013, s. 136-137) - białoruski neutralny odpowiednik èkskursiâ 'wycieczka';

pol. frukt 1 . daw. «owoc jakiejś rośliny» 2. daw. «efekt jakichś działań»-białoruski neutralny odpowiednik frukt 'owoc';

pol. harmata daw. «armata» - białoruski neutralny odpowiednik garmata 'armata'; pol. kanikuła przestarz. «upał, lato, wakacje» - białoruski neutralny odpowiednik kanikuly 'wakacje, ferie';

pol. pocztylion 1. daw. «listonosz» 2. daw. «woźnica pojazdu pocztowego»- białoruski neutralny odpowiednik paštal'ën 'listonosz, doręczyciel';

pol. $r a b$ daw. «niewolnik lub sługa» - białoruski neutralny odpowiednik $r a b$ 'niewolnik';

pol. strawa daw. «pożywienie» - białoruski neutralny odpowiednik strava 1 . 'jedzenie, pokarm', 2. 'danie';

pol. wieczerza daw. «posiłek wieczorny», przestarz. «kolacja» (por. Kaleta 2013, s. 137) - białoruski neutralny odpowiednik vâcèra 'kolacja';

pol. zakon daw. "prawo (m.in. Stary Zakon, Nowy Zakon), dzisiaj tylko w znaczeniu 'zgromadzenie religijne lub świeckie, którego członkowie są związani ślubami i żyją według ściśle określonych reguł» - białoruski neutralny odpowiednik zakon 'prawo, ustawa'.

Nie wszystkie znaczenia polskiego leksemu muszą być zakwalifikowane jako archaiczne. Czasem tylko drugie lub kolejne znaczenie ma w słowniku kwalifikator, np.:

pol. awans 1. «przejście na wyższe stanowisko» 2. «zdobycie wyższej pozycji społecznej, towarzyskiej m.in.» 3. «zajęcie wyższego miejsca w klasyfikacji» 4. daw. «suma pieniężna stanowiąca zaliczkę na rachunek jakichś należności» - białoruski neutralny odpowiednik avans 'zaliczka'; 
pol. awantura 1. «gwałtowna kłótnia» 2. daw. «ryzykowne przedsięwzięcie» 3. daw. «osobliwe zdarzenie albo niezwykła przygoda» - białoruski neutralny odpowiednik avantura 1. 'awantura, kłótnia' 2. 'przygoda';

pol. ekonomika 1. "gałąź ekonomii badająca zjawiska występujące w określonym dziale gospodarki, w jakimś rodzaju przedsiębiorstw»; 2. «dawniej, potocznie: gospodarka, gospodarstwo» - białoruski neutralny odpowiednik èkanomika 1. 'ekonomika', 2. 'gospodarka';

pol. garderoba 1. wszystkie ubrania, jakie się ma» 2. «ubranie noszone w danej chwili» 3. «niewielkie pomieszczenie do przechowywania ubrań; dawniej: pokój, gdzie przechowywano odzież i gdzie przebywały służące, które się nią opiekowały» 4. «pokój, w którym się ubierają i charakteryzują aktorzy przed wyjściem na scenę» 5. daw. «przechowalnia ubrania»-białoruski neutralny odpowiednik gardèrob 1. 'szafa na ubrania, garderoba' 2. 'szatnia';

pol. kompania 1. «grono znajomych spędzających wspólnie czas» 2. «pododdział w różnych rodzajach wojsk, składający się z kilku plutonów» 3. «stowarzyszenie kupców, zakładane dawniej w celu prowadzenia handlu za granicą» 4. daw. «towarzyszenie komuś» - białoruski neutralny odpowiednik kampaniâ 1. 'towarzystwo' 2. 'spółka';

pol. marka 1. «znak firmowy umieszczany na wyrobach» 2. «jakość lub gatunek wyrobów danej firmy» 3. «dobra opinia»4. daw. «znaczek pocztowy» 5. daw. «numerek lub żeton» - białoruski neutralny odpowiednik marka 1.'znaczek', 2. 'znak, cecha', 3. 'marka, gatunek';

pol. miesiąc 1. «dwunasta część roku obejmująca od 28 do 31 dni» 2. przestarzale, gwarowo albo poetycko «księżyc» - białoruski neutralny odpowiednik mesâc 1. 'księżyc', 2. 'miesiąc';

pol. pohybel 1. «konstrukcja, na której wiesza się skazańców oraz sama kara śmierci przez powieszenie; szubienica»; 2. daw. «o nieszczęściu lub zgubie, zatraceniu; dziś tylko w przestarzałym wyrażeniu: na pohybel - na zgubę, na zatracenie, na nieszczęście» - białoruski neutralny odpowiednik gibel' 'zguba, zagłada, zatracenie, zginięcie';

pol. wyraj 1. «miejsce odpoczynku; też: odpoczynek» 2. daw. «ciepłe kraje, do których odlatują ptaki; też: odlot ptaków na zimę» - białoruski neutralny odpowiednik vyraj 'ciepłe kraje, wyraj'.

Zanalizowane przykłady leksykalne mogą wystąpić w języku polskim Białorusinów (i innych Słowian) uczących się i używających języka polskiego. Cudzoziemcy mogą je także zaczerpnąć z literatury polskiej. Rzadko kiedy słownictwo nacechowane stylistycznie w sposób poważny zakłóca komunikację, rzadko kiedy także słownictwo nacechowane stylistycznie $\mathrm{w}$ jednym języku, mające $\mathrm{w}$ języku uczących się neutralne odpowiedniki, bywa analizowane na zajęciach, gdyż wymagałoby to od lektora znajomości języka ojczystego osób, które uczy, co z oczywistych względów nie zawsze jest możliwe. Jednakże różne rodzaje homonimów 
międzyjęzykowych powinny być (choćby w minimalnym stopniu) sygnalizowane uczącym się i uwzględnianie na kursach oraz w podręcznikach do JPJO, zwłaszcza w grupach słowiańskich, a już na pewno na slawistykach i zagranicznych polonistykach, kształcących kandydatów na tłumaczy czy nauczycieli, którzy odznaczają się dużą świadomością językową oraz dużą motywacją do doskonalenia swojej polszczyzny. Istnieje zapotrzebowanie na specjalne zestawy ćwiczeńn ${ }^{3}$, które zwracałyby uwagę na subtelne międzyjęzykowe różnice stylistyczne. Waga zagadnień stylistycznych jest podkreślana przez polonistów (np. Zdunkiewicz-Jedynak 2006; Markowski 2004, 2007, s. 59). Potrzeba zatem także czujności lektora, który byłby pierwszym przewodnikiem po meandrach polskiej stylistyki. Należy także wspomnieć, że takie analogiczne trudności mają Polacy uczący się języków wschodniosłowiańskich (w tym języka białoruskiego, języka ukraińskiego i języka rosyjskiego, por. np. Załecka 1997; Czernysz 2005; Gasek 2012). Często wpadają oni w pułapkę komunikatywności (więcej zob. Skalscy 1995) i nie przykładają należytej uwagi do niuansów stylistycznych, mogących być przyczyną błędów stylistycznych, czasem zabawnych. Omawiany problem dotyczy i innych blisko spokrewnionych języków słowiańskich (por. np. Mitreva 2012), co świadczy o jego uniwersalnym charakterze, którego nie można pominąć w procesie kształcenia językowego (podkreślała to mocno Pančíková w cytowanych pracach, zob. Pančíková 2004, 2005). Niewątpliwie zarówno thumaczom, jak i wszystkim osobom uczącym się konkretnych języków słowiańskich pomocny byłby słowniczek dwujęzyczny leksemów nacechowanych stylistycznie w jednym języku i neutralnych (bądź nacechowanych inaczej) w drugim języku. Słowniczki takie zestawiają na własne potrzeby sami uczący się lub ich nauczyciele. Warto byłoby dołożyć starań, by powstawały profesjonalne dwujęzyczne wydania leksykograficzne tego typu. Inną kwestię stanowi kształcenie nauczycieli języków obcych. W tym niełatwym procesie warto wciąż zwracać uwagę właśnie na leksykę nacechowaną stylistycznie i uczulać przyszłych lektorów na problemy, jakie taka leksyka może powodować podczas nauki języka polskiego przez obcokrajowców.

\section{BIBLIOGRAFIA}

Bednaž M., 2002, Pol'sko-ukraïns 'ka mižmovna omonìmiâ, Opole.

Biełocka T., 1997, Trudności młodzieży grodzieńskiej w przyswajaniu rodzaju gramatycznego niektórych rzeczowników polskich, w: B. Janowska, J. Porayski-Pomsta (red.), Język polski w kraju i za granica, t. II, Warszawa, s. 34-40.

Chylak-Schroeder T., Głuszkowska-Babicka J., Jasińska-Socha T., 2012, Słownik białorusko-polski, Warszawa.

${ }^{3} \mathrm{Na}$ wzór zbioru ćwiczeń francusko-rumuńskich homonimów, którego tytuł można przetłumaczyć z francuskiego jako Strzeż się fałszywych przyjaciót (Pelea 2014). 
Cukrowska K., 1978, Problemy językowe w szkołach podstawowych na terenach zamieszkatych przez ludność polska i białoruska, „Polonistyka”, nr 2, s. 112-114.

Czernysz T., 2005, Polsko-ukraińskie pułapki językowe: korzyści i trudności nauczania języka polskiego w kontekście bliskości lingwogenetycznej i typologicznej, w: P. Garncarek (red.), Nauczanie języka polskiego jako obcego i polskiej kultury w nowej rzeczywistości europejskiej. Materiały z VI Międzynarodowej Konferencji Glottodydaktycznej, Warszawa, s. 477-481.

Dąbrowska A., Dobesz U., Pasieka M., 2010, Co warto wiedzieć. Poradnik metodyczny dla nauczycieli języka polskiego jako obcego na Wschodzie, Warszawa.

Dubisz S., 1991, Archaizacja w XX-wiecznej polskiej powieści historycznej o średniowieczu, Warszawa.

Foland-Kugler M., 1998, Uczymy polskiego na Wschodzie. Poradnik metodyczny, Warszawa.

Gasek B., 2012, Leksiko-semantičeskâ̂ interferenciâ v processe perevoda (na materiale russkogo i polskogo jazykov), Wrocław.

Grosbart Z., 1984, Teoretyczne problemy przekładu literackiego w ramach języków bliskopokrewnych (na materiale języka polskiego i języków wschodniosłowiańskich), Łódź.

Guszczewa O., 2006, Typy błędów leksykalnych w pracach białoruskich studentów, w: S. Važnik, A. Kožynava (red.), Aktual'nyâ prablemy palanistykì, Mìnsk.

Kaleta R., 2010, Câžkascì pol'skae movy: pamylkì belarusaŭ, âkiâ vyvučaûc' pol'skuû movu, „Arche" nr 4, s. 358-400.

Kaleta R., 2011, Janka, Janko, Janek czy Jan Kupała - o fatszywych przyjaciołach thumacza na przyktadzie antroponimii, „Acta Albaruthenica”, t. 11, s. 212-216.

Kaleta R., 2013, Złudne odpowiedniki białorusko-polskie, „Studia z Filologii Polskiej i Słowiańskiej”, t. 48, s. 123-141.

Kaleta R., 2014, Białorusko-polska homonimia międzyjęzykowa, Warszawa.

Kaleta R., 2015a, Polsko-białoruska lapsologia glottodydaktyczna, Warszawa.

Kaleta R., 2015b, O białoruskich pozornych odpowiednikach polskich archaizmów, „Slavia”, nr 4, s. $428-440$.

Kuźmiuk J., 1982, Regionalizmy językowe uczniów szkót podstawowych Białostocczyzny. Zagadnienia metodyczne, Białystok.

Lotko E., 1992, Zrádná slova v polštine a češtine. Lexikologický pohled a slovnik, Olomouc.

Markowski A. (red.), 2004, Wielki słownik poprawnej polszczyzny PWN, Warszawa.

Markowski A., 2007, Kultura języka polskiego. Teoria. Zagadnienia leksykalne, Warszawa.

Mitreva M., 2012, Kompetencja komunikacyjna bułgarskich użytkowników języka polskiego (aspekt glottodydaktyczny), Warszawa.

Pančíková M., 2004, Archaizmy, w: A. Dąbrowska (red.), Wroctawska dyskusja o języku polskim jako obcym. Materiały z międzynarodowej konferencji stowarzyszenia „Bristol”, Wrocław, s. $283-287$.

Pančíková M., 2005, Zdradnosti pol’skej a slovenskej lexiky, Opole.

Pelea A., 2014, Méfiez-vous des faux amis!, Cluj-Napoca.

Skalscy A. i T., 1995, Pułapka komunikatywności, w: J. Mazur (red.), Kształcenie sprawności komunikacyjnej Polaków ze Wschodu, Lublin, s. 49-57.

Stownik języka polskiego, [online], http://sjp.pl [15.09.2014].

Słownik języka polskiego PWN, [online], http://sjp.pwn.pl [15.09.2014].

Smułkowa E., 2001, Język i kultura białoruska w kontakcie z sąsiadami, Warszawa.

Smułkowa E., 2002, Białoruś i pogranicza: studia o języku i społeczeństwie, Warszawa.

Smułkowa E., 2007, Język polski na Białorusi, w: J. Mazur, M. Rzeszutko-Iwan (red.), Język polski jako narzędzie komunikacji we wspótczesnym świecie, Lublin, s. 195-206.

Stasin'ska P., 1990, Mežz"âzykovaâ omonimiâ v russko-pol'skom sopostavlenii, Zelënaâ Gura.

Šakun L., 1999, Belaruska-pol'skiâ moŭnyâ kantakty ŭ XX stagoddzi, „Rodnae slova”, nr 4, s. $62-67$.

Šuba P.P., 1993, Pol'ska-belaruskiâ leksičnyâ adpavednascì na sučasnym ètape, w: G. M. Mezenka (red.), Belaruska-ruska-pol'skae supastaŭlâl'nae movaznaŭstva i litaraturaznaŭstva. Matèryjaly 2-j mižnarod. nav. kanf., Vicebsk 5-6 lûtaga 1993, Vìcebsk. 
Załecka O., 1997, Z praktyki nauczania języka polskiego jako obcego na Ukrainie Zachodniej, w: B. Janowska i J. Porayski-Pomsta (red.), Język polski w kraju i za granica. Materiały Międzynarodowej Konferencji Naukowej Polonistów Warszawa 14-16 września 1995 r., t. II, Warszawa, s. 259-269.

Zdunkiewicz-Jedynak D., 2006, ABC stylistyki, w: M. Bańko (red.), Polszczyzna na co dzień, Warszawa, s. 33-96.

Radostaw Kaleta

\section{ON STYLISTIC MARKED VOCABULARY IN TEACHING BELARUSIANS THE POLISH LANGUAGE}

Keywords: Belarusian language, Polish language, didactics of foreign languages, stylistics, Stylistic Marked Vocabulary

Summary. The aim of the present paper is to describe the idea of stylistic marked vocabulary in teaching Polish in Belarusian environment. Particular attention is paid to the nuances of different stylistic tokens Polish and Belarusian, which apparently seem very similar to each other. The collected material can help lectors working with Belarusians in stressing the particular issues of stylistic teaching of Polish language and Belarusians learning the Polish language - in avoiding stylistic errors. The issue of stylistic marked vocabulary seems to be detracted from in the field of foreign language didactics. In practice, language learners often have little awareness of such language errors which often do not hinder communication. Therefore, a need for devising dedicated exercises that would help learners not only notice this subtle linguistic difficulty but also eliminate its consequences arises. 